УДК

323.1(=163.41)(439)"1901/1909"(093.2)

94:327(470:497.11)"1901/1909"(093.2)

341.7(470:439)"1901/1909"(093.2)

Оригинални научни рад

Примљен: 20. 2. 2017.

Прихваћен: 22. 12. 2017.

Игорь КРЮЧКОВ

Северо-Кавказский федеральный университет, заведующий кафедрой зарубежной истории, политологии

и международных отношений, г.Ставрополь

igory5@yandex.ru

\title{
Сербия и Сербы Венгрии в донесениях Генерального консульства России в Будапеште в начале XX века (1901-1909 гг.)
}

\begin{abstract}
Резюме: Данная статья посвящена восприятию дипломатами генерального консульства России в Будапеште положения сербов Венгрии и развития независимой Сербии. В ней анализируется политика наступления правительства Венгрии на права сербов и причины этого явления. В статье отмечается тесная связь между борьбой Сербии за укрепление своих позиций на Балканах и взаимоотношениями Будапешта с сербами Венгрии.

ключевые Слова: Сербы, Сербия, Венгрия, мадьяризация, православная церковь, автономия, собор, Нови Сад, Будапешт
\end{abstract}

В начале XX в. донесения российских дипломатов, работавших в Австро-Венгрии являлись основным источником получения информации из империи Габсбургов для правящих кругов России. Частично некоторые донесения публиковались на страницах официальных изданий, таких как «Вестник промышленности, торговли и финансов», «Сборники консульских донесений» и др. Данные публикации в основном отражали различные стороны экономической жизни Австро-Венгрии и развития ее внешнеэкономической деятельности, они предназначались, прежде всего, для деловой элиты страны. В России в начале XX в. развернулась оживленная дис- 
куссия о необходимости развития внешней торговли страны и главным образом с государствами Балканского полуострова и Ближнего Востока. ${ }^{1}$ В Санкт-Петербурге понимали, что без расширения экономического проникновения в регион будет невозможно дальнейшее сохранение, тем более расширение политического влияния России на Балканах и Ближнем Востоке. Пример Австро-Венгрии представлялся наиболее востребованным и полезным для российских предпринимателей и государственных структур, поскольку империя Габсбургов находилась примерно на одном уровне с Россией в области развития экономики, но при этом она достигла значительно больших результатов во внешнеэкономических связях с Сербией, Болгарией, Грецией, Румынией, Османской империей. Изучение австро-венгерского опыта организации внешней торговли становилось одной из задач для российских дипломатов в Австро-Венгрии.

Абсолютно секретными оставались донесения дипломатического корпуса России о внутренней и внешней политике империи Габсбургов. На события, происходившие в Австро-Венгрии, российские дипломаты смотрели через призму интересов России, ее взаимоотношений с Веной, с другими великими державами и раскладом сил на международной арене в конце XIX - начале XX вв. ${ }^{2}$ Внутриполитические проблемы Австро-Венгрии отходили на второй план. Посольство России в Вене четко придерживалось данной линии при освещении положения дел, как в австрийской, так и венгерской половинах империи Габсбургов.

Несколько иначе обстояли дела при организации деятельности российских генеральных консульств и консульств, расположенных в столицах и в других городах Австро-Венгрии. Они позволяли себе отход от большой политики, сосредоточившись на анализе внутриполитических событий в регионах пребывания. К тому же, в начале XX в. МИД России начинает несколько менять отношение к информации, поступавшей из Австро-Венгрии, понимая, что без изучения внутриполитических процессов в европейских государствах невозможно выстраивать полноценные связи с ними, тем более прогнозировать поведение своих оппонентов.

На территории венгерской половины империи Габсбургов (Транслайтании) действовало две дипломатические миссии: Гене-

1 „Наша хроника“, Торгово-промышленный Юг, № 19, (Одесса, 1913), 65-67.

2 Н. Д. Ратнер, Очерки истории пангерманизма в Австрии в конще ХІХ в. (Москва: Наука, 1970), 173. 
ральное консульство в Будапеште и консульство в Фиуме (совр. Риека - прим. И. К.). Пальма первенства в подготовке донесений в посольство России в Вене, безусловно, принадлежало генеральному консульству в Будапеште, обладавшему большими ресурсами и возможностями. Не редко между генеральным консульством в Будапеште и консульством в Фиуме возникали разногласия при оценке одних и тех же событий, в частности взаимоотношений венгерского правительства с Хорватией.

В январе 1901 г. генеральный консул России в Будапеште князь В. Львов в донесении в российское посольство в Вене отмечал общее изменение отношения венгерского правящего класса к славянским народам Венгрии. ${ }^{3}$ Данное обстоятельство объяснялось опасениями Будапешта по поводу усиления влияния славян на политическую жизнь австрийской половины империи Габсбургов. Правительство Венгрии пыталось заигрывать со славянами. Однако делало оно это, по мнению дипломата, крайне неумело и без четкого представления стратегии и тактики данной политики: «подобная роль совершенно непривычна мадьярам в продолжении 1000 лет эксплуатировавших эти народы». Первыми шагами в реализации политики так называемого компромисса со славянами, становятся усилия правительства по улучшению положения русин в Подкарпатской Руси.

Впервые сербская тематика в донесениях консула появляется в связи с кончиной в феврале 1901 г. в Вене бывшего короля Сербии Милана Обреновича. В. Львова привлекла реакция венгерского общества на данное событие, и прежде всего, периодической печати страны. Большинство венгерских газет критиковало морально-нравственные качества бывшего монарха, не раз попадавшего на страницы «желтой прессы». В тоже время венгерские журналисты высоко оценивали деятельность Милана в качестве политика, ставшего, по их мнению, истинным защитником национальных интересов Сербии. С первой частью оценки Милана В. Львов полностью соглашался. Однако он сомневался в результатах политической деятельности бывшего короля, с 1881 г. занимавшего проавстрийские позиции. ${ }^{5}$

3 Архив внешней политики Российской империи (далее - АВПРИ). Ф. 151. Политархив. Оп. 482. Д. 575. Л. 3.

4 Там же.

5 Там же. Л. 9. 
В январе 1902 г. генеральный консул А. Львов докладывал в посольство о реакции Сербии на поездку эрцгерцога Франца Фердинанда в Санкт-Петербург. Внимание дипломата привлекала спокойная реакция короля Сербии Александра на это событие, что вызвало благоприятное впечатление в Венгрии. В этой связи Будапешт предпринимает ряд репрессивных мер против сербских политиков и сербских газет страны, критиковавших короля Александра и его политику. ${ }^{6}$

В апреле 1902 г. российский дипломат направляет в посольство России в Вене большой отчет под название «Церковная и школьная автономия сербов в Венгрии», где он раскрывает историю создания, структуру автономии, порядок формирования ее органов управления, в том числе Народно-церковного собора. Особое место консул обращал внимание на значительную собственность, находившуюся под контролем сербской православной церкви в Венгрии Карловицкого патриархата. Появление данного донесения во многом было связано с выборами нового состава депутатов собора и подготовкой его заседания.

Сербская церковная и школьная автономия, по мнению А. Львова, к началу XX в. столкнулась с двумя серьезными проблемами, способными существенным образом нарушить право сербов на автономию. Первый конфликт возник между правительством Венгрии и большинством членов собора, поскольку Будапешт стремился расширить свое влияние на принятие решений собором. ${ }^{7}$ Второй конфликт, разгорелся между духовенством и как отмечал консул «народом». Таким образом, консул первоначально четко отделял духовенство от народа. По его мнению, в основе данного конфликта лежало стремление епископата сохранить незыблемость автономии, не предпринимая ни каких изменений в ее характере, чтобы не допустить светских лидеров к управлению автономией. Епископат желал монопольно контролировать автономию. ${ }^{8}$

Рассматривая предысторию конфликта между светскими лидерами, представлявшими интересы всего сербского народа, и духовенством А. Львов обращался к событиям 1892 г., когда епископат предложил изменить процедуру выборов части членов собора, тем самым еще более усиливая свои позиции в нем. Тогда уда-

6 АВПРИ. Ф. 151. Политархив. Оп. 482. Д. 577. Л. 3.

7 Там же. Л. 52.

8 Там же. Л. 33. 
лось отклонить данный проект. Особенно А. Львов отмечал всплеск противоречий между духовенством и народом в 1897 г., при очередном обсуждении вопроса об изменении процедуры выборов депутатов. ${ }^{9}$ В этом конфликте духовенство поддержал премьер-министр Д. Банфи, что на взгляд консула, подчеркивало тесную связь сербского духовенства с правящими кругами Венгрии. Разумеется, собор отказался идти на уступки духовенству, после чего он распускается. Отдельной критики со стороны российского дипломата подвергся Карловицкий патриарх сербской православной церкви Георгий (Бранкович), возглавлявший патриархат с 1890 по 1907 гг. Он обвинялся в недальновидности, личных корыстных действиях и в тесных связях с правительством Венгрии. Действия патриарха, по мнению консула, самым негативным образом сказались на положении дел внутри сербской автономии. Раскол между народом и духовенством только нарастал, финансовые ресурсы, получаемые от церковной собственности, тратились неэффективно, многие благотворительные фонды оказались в сложной экономической ситуации. ${ }^{10}$

Внимание российского дипломата привлекла политическая борьба, развернувшаяся во время подготовки выборов в собор весной 1902 г. По его мнению, Сербская радикальная партия при помощи части сербов Хорватии и Славонии развернула активную агитационную кампанию, используя для этого любые средства, в том числе незаконные (подкуп избирателей, шантаж и т.д.) с целью получения в соборе относительного большинства. ${ }^{11}$ Отчасти им это удалось сделать. Радикалы потеснили не только позиции духовенства, но и представителей традиционных сербских партий и общественных движений, прежде всего либералов.

А. Львов подробно останавливается на анализе деятельности собора, открывшегося в июне 1902 г. Консул обратил внимание на примирительный тон выступления патриарха, призывавшего к единству сербов и к конструктивной работе собора, а также представителя короля, вице-президента парламента Венгрии Б. Таллиана де Визека. Свою речь он прочитал на венгерском языке, что вызвало недовольство со стороны ряда депутатов собора от радикалов. Однако консул акцентировал внимание на высказываниях королевского представителя о братской близости сербского и венгерского

9 Там же. Л. 53.

10 Там же.

11 Там же. Л. 135. 
народов, о вкладе сербов в развитие Венгрии, об их ответственности при принятии решений на соборе, о необходимости единства действий большинства собора с духовенством. А. Львов не верил в искренность данных заявлений, так как за ними скрывались попытки правительства Венгрии поддержать оппортунистический курс патриарха Георгия и поддерживавших его представителей клира. ${ }^{12}$ Неслучайно, что король запретил рассматривать на соборе все жалобы по поводу действий патриарха Георгия и вопрос о свободной вакансии епископа в г.Темешваре (совр. Темишоара - прим. И. К.) до окончательного решения вопроса об управлении имуществом православной церкви.

Финансовые и имущественные вопросы становятся большой проблемой во взаимоотношениях между духовенством и светскими политиками. К тому же само венгерское правительство, на взгляд консула, было, не прочь контролировать средства, получаемые от управления собственностью сербской православной церкви. Сразу после начала работы собора его делегаты провели ревизию финансовых ресурсов автономии и признали неудовлетворительным положение дел с их управлением и передали соответствующий документ правительству. Российский дипломат признавал, что на первых порах работы собора, радикалы действовали крайне осторожно, стремясь не обострять отношения с Будапештом, чтобы максимально продлить работу собора и решить на нем наиболее важные проблемы из жизни сербской автономии. ${ }^{13}$ Либералы тут же обвинили радикалов в заискиваниях перед правительством. Консул больше в данном случае разделял позицию радикалов при всем отрицательном отношении к ним. Однако, на взгляд дипломата, сдержанность радикалов не была длительной, вскоре они переругались с делегатами от Хорватии и Славонии, а затем между собой, что ускорило закрытие заседания собора. ${ }^{14}$

Таким образом, А. Львов признавал полную неспособность нового собора работать эффективно на благо всего сербского народа, поэтому после шести недель бесплодных дискуссий он распускается. Одновременно консул начинает менять свое отношение к противопоставлению духовенство-народ. Он становится не столь категоричным в собственных рассуждениях, осознавая глубокий

12 Там же. Л. 143.

13 Там же. Л. 130.

14 Там же. 
раскол между самими светскими деятелями, представляющими интересы различных слоев населения и политических групп, он отказывается от идеализации действий сербских политиков, тем самым понятие «единый народ» размывалось. Постепенно дипломат смягчает оценки деятельности духовенства, полагая, что многие его предложения шли на благо сербскому народу.

В начале 1903 г. собор принял решение о лишении духовенства монопольного права на управление собственностью монастырей. Радикалы предложили передать его в аренду, а получаемые средств делить между духовенством и специальными фондами, созданными для развития сербского образования и культуры. Духовенство выступило категорически против такого поворота событий, обратившись за помощью к правительству Венгрии, радикалы также апеллировали к нему.

Российский дипломат с большой тревогой следил за развитием событий. Он боялся активного вмешательства правительства Венгрии в дела сербской автономии, поскольку разногласия между светскими политиками и духовенством, а тем более их обращения к Будапешту за содействием в разрешении, возникшей конфликтной ситуации, открывали прямую дорогу для ограничения автономии сербов. ${ }^{15}$ А. Львов практически не сомневался в поддержке правительством духовенства, так как оно не доверяло радикалам. Венгерские политики их подозревали в попытках использования средств, получаемых от управления церковным имуществом для ведения политической агитации в своих целях. ${ }^{16}$ В этом абсолютно был убежден и сам генеральный консул. Он не сомневался в желании радикалов под красивыми лозунгами присвоить часть средств для ведения собственной политической деятельности.

В декабре 1903 г. Франц-Иосиф I подтвердил права духовенства на бесконтрольное управление церковным имуществом. Радикалы попытались вновь обратиться со специальным обращением к премьер-министру Венгрии И. Тисе, но из этого ничего не получилось. А. Львов не считал поражение радикалов, поражением сербский народ и его автономии. Более того, в произошедших событиях дипломат видел и позитивный момент. Его настораживали атеизм и социалистическая риторика многих лидеров радикальной партии, самым негативным образом сказывавшихся на нравственном обли-

15 АВПРИ. Ф. 151. Политархив. Оп. 482. Д. 578. Л. 66.

16 Там же. 
ке сербов Венгрии. Он больше ориентировался на поддержку сербской православной церкви и ее духовенства. ${ }^{17}$ Именно в церкви дипломат видел силу, которая на протяжении многих веков сохраняла национальную и культурную идентичность сербов, объединяла их и выступала в качестве выразителя воли всего сербского народа.

14 февраля 1903 г. в Венгрию приехал сербский король Александр со своей супругой. Консул доносил о теплом и восторженном приеме, оказанном монарху сербским населением Южной Венгрии. Российский дипломат отмечал нейтральный тон выступлений Александра, выстроенных в духе добрососедства сербов и венгров, дружбы между Сербией и Австро-Венгрией. Дипломат обратил внимание на спокойный и доброжелательный тон высказываний венгерских газет по поводу визита монарха. Они не беспокоились из-за Сербии, полагая, что она находится в полной зависимости от Австро-Венгрии. ${ }^{18}$ А. Львов воздержался от комментариев в данном случае.

Большой резонанс в Венгрии вызвал переворот 11 июня 1903 г. в Белграде, закончившийся свержением династии Обреновичей. А. Львов отмечал обеспокоенность и некоторую растерянность венгерской общественности по этому поводу. Для Будапешта переворот стал полной неожиданностью. Многие в случившемся обвиняли премьер-министра К. Селля, «проспавшего» переворот. А. Львов предсказывал близкую отставку премьер-министра «по совокупности заслуг». ${ }^{19}$

В начале лета 1904 г. делегация из 120 предпринимателей Сербии посетила Венгрия с целью налаживания деловых контактов. Консул пристально отслеживал политический фон приезда делегации и итоги ее переговоров с венгерскими политиками и экономистами. Накануне визита сербской делегации одна из ведущих газет страны «Pester Lloyd», близкая к правительственным кругам, опубликовала информацию о желательности окончательного присоединения Боснии-Герцеговины к Австро-Венгрии. Появление данной информации привело к негативным комментариям в Белграде, и визит оказался на грани срыва. Правительство Венгрии выступило со специальным сообщением, раскритиковавшем позицию газеты по поводу дальнейшей судьбы Боснии-Герцеговины.

17 Там же. Л. 257.

18 Там же. Л. 29.

19 Там же. Л. 117. 
А. Львов отмечал радушие, с которым в Венгрии встретили сербскую делегацию. ${ }^{20}$ Венгерская пресса и политики много говорили о желании сохранить добрососедские отношения между Сербией и Австро-Венгрией, а также перспективах экономического сотрудничества Венгрии с Сербией. Стороны пришли к мнению о целесообразности приезда венгерской делегации в Сербию летом 1905 г. Российский дипломат особо не комментировал данные высказывания, отмечая, что нормальному развитию экономических связей Венгрии с Сербией мешала конкуренция со стороны австрийской промышленности, ее товары доминировали в Сербии, перекрывая доступ в страну промышленным товарам из Венгрии. ${ }^{21}$

Большое внимание консул уделил итогам парламентских выборов 1905 г. в Венгрии, их результаты оказались неутешительными для представителей национальных меньшинств, в частности словацкие партии потеряли все места. В парламенте оказалось всего два сербских депутата, причем один из них избирался от венгерской партии. ${ }^{22}$ А. Львов признавал невозможность в виду, сложившейся в Венгрии политической системы партиям национальных меньшинств участвовать на равных в парламентских выборах. Поэтому многие из них, в том числе сербы, на выборах 1905 г. поддержали венгерскую оппозицию.

В конце 1906 - начале 1907 гг. начал свою работу очередной Народно-церковный собор сербов. На выборах в собор радикалы получили большинство, они заняли 44 мест из 82. По данным российского дипломата за радикалов в основном голосовали сербы Баната и других районов Южной Венгрии, за их противников сербы Хорватии и Славонии. ${ }^{23}$ Однако, деятельность собора, по мнению российского дипломата, в очередной раз была парализована очередным витком борьбы между духовенством и радикалами из-за имущества церкви. Причем, он отмечал, жесткую кампанию, развернутую лично против патриарха Георгия. Радикалы и их сторонники обвиняли патриарха в коррупции и в других грехах, требуя предать патриарха суду. ${ }^{24}$ Консул полностью был на стороне патриарха.

\footnotetext{
20 Там же. Л. 82.

21 АВПРИ. Ф. 151. Политархив. Оп. 482. Д. 579. Л. 82-84.

22 АВПРИ. Ф. 151. Политархив. Оп. 482. Д. 580. Л. 22.

23 АВПРИ. Ф. 151. Политархив. Оп. 482. Д. 581. Л. 6.

24 Там же. Л. 5.
} 
На этот раз правительство Ш. Векерле заявило о своей поддержке сербских радикалов и нежелании правительства вмешиваться в ход собора. Российский дипломат не верил в искренность действий Будапешта. Он не сомневался в попытках Ш. Векерле с помощью обострения конфликта сербского духовенства с радикалами привести автономию к нежизнеспособности. В результате чего правительство могло выступить в качестве третейского судьи, диктуя свои условия сербам. ${ }^{25}$

Радикалы, перейдя в наступление на духовенство, по мнению А. Львова, рассчитывали полностью отстранить его от управления финансами. Для реализации данного плана они взяли курс на дискредитацию духовенства среди широких слоев сербского населения. Консул полагал, что патриарх Георгий разгадал план радикалов, активно выступив против их нападок на духовенство. Поэтому они решили отстранить патриарха от власти и привести на патриарший престол своего ставленника, который был бы марионеткой в руках радикалов. ${ }^{26}$ Все беды сербской автономии вновь А. Львов сводил к деструктивной деятельности радикалов, впервые о себе заявивших на соборе 1894 г. и сразу приступивших к борьбе с духовенством.

Патриарх, духовенство и часть мирян покинули собор, призывая правительство приостановить его деятельность на время до выяснения всех фактов, выдвинутых против патриарха. На взгляд консула, Ш. Векреле оказался в очень сложной ситуации, он обещал проверить все обвинения, выдвинутые в адрес патриарха и принять соответствующее решение. С одной стороны, он обещал помощь и содействие радикалам, но им премьер-министр никогда не доверял. С другой стороны, духовенство и патриарх, всегда поддерживавшие правительство, в конфликте короны с венгерской национальной оппозицией поддержали в 1905 г. Франца-Иосифа I и неконституционное правительство Г. Фейервари, а радикалы сделали ставку на оппозицию. ${ }^{27}$

В создавшихся условиях венгерская пресса требовала от правительства срочно вмешаться в конфликт и поставить под полный контроль все религиозные и культурные учреждения сербов, составлявшие костяк их церковной и школьной автономии. Для А.

25 Там же.

26 Там же.

27 Там же. 
Львова это был тревожный сигнал, демонстрировавший истинные намерения правящих кругов в Будапеште по отношению к сербской автономии. По данному поводу он писал в одной из депеш в посольство в Вене: «не может быть сомнения, что венгерское правительство не применет использовать этот конфликт в интересах мадьяризации, в ущерб законным правам сербской православной церкви, так и самой сербской народности в Венгрии». ${ }^{28}$ К тому же и раньше, когда автономия не сталкивалась с острыми внутренними конфликтами, венгерское правительство не редко вмешивалось во внутренние дела сербов. В качестве примера консул приводил ситуацию, возникшую в 1879 г. Тогда Будапешт добился ухода в отставку патриарха Прокопия (Ивачковича), являвшегося большим патриотом сербов и завоевавшего популярность среди них и привел к власти, несмотря на протесты собора своего ставленника - патриарха Германа (Анджелича). ${ }^{29}$

В следующей депеше от 9 февраля 1907 г. А. Львов вновь возвращается к анализу ситуации вокруг сербской автономии. По его мнению, автономия, дарованная императором Леопольда I в конце XVII в., ставила сербов в привилегированное положение по сравнению с другими национальными меньшинствами Венгрии. ${ }^{30}$ Другое дело, что они не смогли ею воспользоваться в полной мере из-за внутренних конфликтов и давления Будапешта.

Консул среди сербов Венгрии выделял три основные общественно-политические силы. Первая, так называемая «клерикальная партия», включала духовенство во главе с патриархом, она имела собственное периодическое издание «Сербский Сион». Партия ориентировалась на сохранение доминирования духовенства в жизни сербской автономии, исключение светских лиц от процедуры избрания духовенства и изменение состава собора в пользу представителей клира. Данная группа добивалась руководящей роли духовенства в жизни всех сербских общин. Клерикальная партия сохраняла лояльность правительству, и пользовалось его определенной поддержкой. По мнению консула, духовенство всеми силами стремилось сохранить контроль над школами, понимая, что без

28 Там же. Л. 8.

29 АВПРИ. Ф.151. Политархив. Оп. 482. Д. 1508. Л. 9.

30 АВПРИ. Ф.151. Политархив. Оп. 482. Д. 581. Л. 9. 
религиозного образования молодежи оно не сможет сохранить свои позиции в автономии в будущем. ${ }^{31}$

Вторая партия, выделяемая дипломатам - радикальная, возглавляемая главным редактором газеты «Застава» Я. Томичем, самая массовая и демократичная. Я.Томича, консул считал, выдающимся политиком Венгрии. Однако его сильно смущали социалистическая идеология партии, самым негативным образом сказывающаяся на политических взглядах сербов и прежде всего молодежи, а также ее стремление подорвать авторитет среди народа представителей верхов общества и духовенства. ${ }^{32}$ По мнению А. Львова, радикалы допускали одну крупную стратегическую ошибку. Они не понимали, что уничтожив высшие сословия общества и духовенство, радикалы, обезглавив сербский народ, сделают его легкой добычей для мадьяризаторов. ${ }^{33}$ Поэтому консул в очередной раз подтвердил свое отрицательное отношение к сербским радикалам.

Либеральная партия представляла третью политическую силу сербов Венгрии. Либералов, А. Львов называл теоретиками, людьми 60-70-х гг. XIX в., не пользовавшихся большой популярностью в народе. ${ }^{34}$ Они всегда отрицательно относились к мадьяризации и подчеркивали культурную общность всех славянских народов Балканского полуострова, что вызывало симпатии у дипломата.

В восприятии А. Львова особенностью развития сербского национального движения Венгрии являлись его попытки установления компромисса с венгерским правительством. С помощью чего сербские лидеры стремились защитить сербов в Хорватии и Славонии от хорватского национализма. ${ }^{35}$ Будапешт также проявлял заинтересованность в поддержке сербов в Хорватии и Славонии, используя их в качестве противовеса чрезмерным амбициям хорватских политиков. Правда, консул признавал, что в последнее время между сербами и хорватами наметилось сближение. В случае, если хорваты откажутся от политики дискриминации сербов, то это позволит создать сербо-хорватский блок, который, по мнению А. Львова, станет мошной преградой на пути мадьяризации. Тем белее, сближению сербов с хорватами способствовала идея югославянско-

\footnotetext{
31 Там же. Л. 10.

32 Там же.

33 Там же.

34 Там же. Л. 10-11.

35 Там же. Л. 11.
} 
го братства, широко распространенная у сербов. Кроме этого консул выделял русофильство, как одну из черт национального самосознания сербов, передавшуюся от поколения к поколению на протяжении многих веков. ${ }^{36}$

Для А. Львова, угроза мадьяризации сербов являлась реальной проблемой, правда она не была столь острой как у словаков или русин Подкарпатской Руси. В отличии от других национальных меньшинств сербы обладали хорошей системой образования, получавшей большую финансовую подпитку из различных благотворительных фондов и от частных лиц. По мнению дипломата, школа стала рассадником сербского национального самосознания и очагом сохранения народной культуры сербов. ${ }^{37}$ Поэтому сербы хотели увеличить количество школ, а правительство тормозило данный процесс. Более того оно пошло в наступление на сербские школы, переводя часть учебного процесса на венгерский язык в ущерб сербскому языку. На взгляд консула, если начальная школа еще как то отбивалась от тотальной мадьяризации, то на уровне гимназий это было сделать сложно. Правительство отказывалось открывать новые гимназии, поэтому сербской гимназии в Нови Саде пришлось создать дополнительный класс, чтобы спасти сербскую молодежь от мадьяризации. Тем не менее, по данным консула в начале XX в. более 700 сербских юношей посещали венгерские гимназии. Серьезное беспокойство у дипломата вызывало состояние дел в учительских семинариях сербов, где правительство внедрило венгерский язык и сделало его знание обязательным условием для получения должности учителя. ${ }^{38}$ Высокую оценку от дипломата получила деятельность культурно-просветительских организаций, периодических изданий сербов, система грантов по поддержке талантливой молодежи.

Успехи сербов Венгрии, по мнению российского дипломата, во многом зиждились на их достижениях в области экономики. Сербы не только смогли сохранить свое землевладение на юге Венгрии, но и значительно его расширить главным образом за счет плодородных земель. Более $90 \%$ сербских крестьян, по сведениям консула, охватывалось различными формами кооперации, что стало за-

\footnotetext{
36 Там же.

37 Там же. Л. 12.

38 Там же. Л. 14.
} 
логом их экономической состоятельности. ${ }^{39}$ Большое значение для экономики сербов, на взгляд консула, имело развитие сербского банковского капитала, в основном сосредоточенного в Загребе. Поэтому, неслучайно, Нови Сад консул называл политическим и духовным центром сербов Венгрии, а их экономическим центром считал Загреб. ${ }^{40}$ Сербские банки обеспечивали сербов дешевым кредитом, тем самым спасая их от ростовщиков, часть прибыли банки направляли на покупку для крестьян земли, племенного скота, расширение виноградников и т.д.

Высокую оценку консула получила деятельность «Союза сербских земледельческих товариществ», который, по его мнению, способствовал распространению среди сербских крестьян современных методов ведения хозяйства, дешевых кредитов, сельскохозяйственной техники и т.д. Крестьяне, входившие в эту организацию, на взгляд консула, отличались особой старательностью в хозяйственной деятельности, они избегали пьянства и азартных игр.

Значительных результатов в Южной Венгрии достигли сербская торговля, промышленность и ремесло. Сила сербского торгово-промышленного класса, по мнению консула, заключалась не только в его инициативе, финансовой состоятельности, но и в объединении в различные организации, координировавшие деятельность предпринимателей и имевшие собственные периодические издания. ${ }^{41}$ А. Львов не сомневался в том, что сербы показали способность решать самые сложные проблемы. Понимая необходимость поддержки ремесленников, они создают общество «Привредник», занимавшейся обучением сербской молодежи и ее трудоустройством в ремесленных мастерских. Показателем достижений сербов Венгрии для консула являлось быстрое развитие у них среднего класса. ${ }^{42}$ В кооперации, создании собственной банковской системы, развитии других экономический структур, консул видел мощный инструмент формирования национального самосознания сербов, их взаимопомощи, они также играли большую роль в борьбе с мадьяризацией. ${ }^{43}$

\begin{tabular}{ll}
\hline 39 & Там же. \\
40 & Там же. \\
41 & Там же. Л. 16. \\
42 & Там же. Л. 18. \\
43 & Там же. Л. 15.
\end{tabular}


Летом 1907 г. управляющий делами генерального консульства в Будапеште В. фон Штральборн обращается к перспективам заключения нового торгового соглашения между Австро-Венгрией и Сербией. Он полагал, что его заключение тормозилось существенными разногласиями, возникшими между австрийской и венгерской половинами империи Габсбургов. Аграрии Венгрии выступали против экономического компромисса с Сербией, боясь потерять сверхдоходы, получаемые в условиях существенного ограничения импорта сельскохозяйственной продукции из Сербии в Австро-Венгрию. ${ }^{44}$

В конце июля 1907 г. пришла информация о смерти патриарха Георгия. Данная новость вызвало большое беспокойство в генеральном консульстве. В. фон Штральборн считал, что смерть патриарха произошла в очень сложный период для сербской автономии, поскольку, воспользовавшись данным событием, венгерское правительство могло начать новое наступление на права автономии. ${ }^{45}$ Первым проявлением этой тенденции становится политика Будапешта по навязыванию сербам кандидатуры нового патриарха Лукиана (Богдановича), являвшегося, по мнению консула, последовательным мадьяроном, который будет послушным исполнителем воли Будапешта в ущерб интересам сербского народа. ${ }^{46}$

В. фон Штральборн полагал, что церковная жизнь сербов Венгрии стала заложницей межпартийной борьбы и столкновения интересов различных политических групп, не имеющей ничего общего с религиозной жизнью сербов. Патриархальная церковная автономия уходила в прошлое, а на ее место приходила светская политическая жизнь. ${ }^{47}$ В этих условиях, на взгляд дипломата, Венгрия уничтожит церковную и школьную автономию сербов в ближайшее время. При этом собор сохранит часть своих прерогатив, но они будут носить либо номинальный характер, либо не будут исполняться на практике. Однако дипломат не сомневался в том, что сербский народ так легко не сдастся, отстаивая собственную свободу и защищая автономию. ${ }^{48}$

\footnotetext{
44 Там же. Л. 131.

45 АВПРИ. Ф. 151. Политархив. Оп. 482. Д. 1508. Л. 33.

46 Там же. Л. 120.

47 Там же.

48 Там же.
} 
В конце июля 1907 г. начал работу очередной сербский собор. Он сразу, по настоянию радикального большинства, отказался обсуждать законы, предложенные митрополичьим советом, став, на взгляд дипломата, ареной очередного витка политической борьбы. Радикалы обрушились с критикой на действия правительства Венгрии, подвергнув абстракции кандидатуру нового патриарха и выдвинув своего кандидата - епископа Г. Змеяновича. ${ }^{49}$ В сентябре 1908 г. дипломат доносил об утверждении Богдановича патриархом, сербом пришлось подчиниться грубому диктату. ${ }^{50}$ В избрании нового патриарха, В. фон Штральборн видел, победу мадьяризаторских сил в сербской автономии.

Одновременно, российский дипломат, признавал, что патриарх Лукиан имел ряд достоинств. Он был молод и энергичен, имел прекрасное образование, обладал хорошими административными качествами. Дипломат выражал острожный оптимизм по поводу того, что возможно новый патриарх все же выступит в защиту сербской автономии, уже находясь в новой должности. ${ }^{51}$ Критикуя патриарха и духовенство за сотрудничество с правительством Венгрии, российские дипломаты отчасти понимали оправданность такой политики, поскольку важно было сохранить всеми доступными средствами автономию сербов, чтобы не дать Будапешту дополнительные основания для ее ликвидации. Они видели, что действия радикалов невольно способствовали установлению контроля Будапешта над автономией, что будет иметь для сербского народа самые отрицательные последствия.

В 1908 г. на Балканском полуострове разворачиваются грандиозные события, разрушившие, сложившийся статус-кво. Младотурецкая революция, аннексия Боснии-Герцеговины, провозглашение независимости Болгарии, осложнение взаимоотношений между Сербией и Австро-Венгрией дестабилизировали ситуацию на полуострове. Дипломаты вынуждены были сосредоточиться на анализе влияния данных событий на внутреннюю и внешнюю политику империи Габсбургов. Особо их волновала вероятность объявления Австро-Венгрией войны Сербии и военные приготовления австро-венгерской армии.

49 Там же. Л. 130.

50 АВПРИ. Ф. 151. Политархив. Оп. 482. Д. 582. Часть 1. Л. 95.

51 Там же. Л. 114. 
В начале ноября 1908 г., после аннексии Боснии-Герцеговины и резкой реакции на эти события Сербии, российский дипломат отмечал рост антисербских настроений в венгерском обществе. ${ }^{52}$ Ведущие периодические издания страны призывали к заключению союза Австро-Венгрии с Османской империей и Болгарией с последующим началом военных действий против Сербии. Дипломат, практически не сомневался в возможном начале войны Австро-Венгрии с Сербией после заключения соглашения Вены с Портой.

В декабре 1908 г. В. фон Штральборн анализирует текст нового торгового соглашения Австро-Венгрии с Сербией. По его мнению, оно полностью было выгодно Венгрии, так как Сербии запрещался ввоз на территорию империи живого скота, а по остальным статьям сербского аграрного экспорта вводились серьезные ограничения, включая повышение таможенных тарифов. ${ }^{53}$ Данное соглашение было невыгодно австрийской половине империи Габсбургов, ибо она страдала от дороговизны продовольствия, поступавшего из Венгрии. Цислайтания сильно зависела от импорта продовольствия. Соглашение, по мнению дипломата, наносило сильный удар по экономическим интересам Сербии. ${ }^{54}$ Кроме давления Будапешта антисербский характер торгового соглашения, на взгляд В. фон Штральборна, объяснялся политическим фактором, так как Сербия в свое время отказалась от размещения военных заказов на предприятиях Австро-Венгрии. В Вене это расценили как проявление демонстрации дружбы по отношению России и Франции. В любом случае, несмотря на всю болезненность свертывания экономических связей с империей Габсбургов, Сербия ослабевала экономическую зависимость от Австро-Венгрии, не без проблем, но находя новые рынки сбыта для своей продукции, в чем консул видел позитивный момент для Белграда. ${ }^{55}$

Правда, парламент Венгрии весной 1909 г. отказался ратифицировать данное соглашение из-за антисербских настроений большинства депутатов. Дипломат отмечал, что от затягивания подписания торгового соглашения Венгрия практически ничего не теряла. Она почти не поставляла промышленные товары в Сербию, а отсутствие сербской продукции вело к росту цен на продовольствие в империи Габсбургов, но австрийские и венгерские аграрии

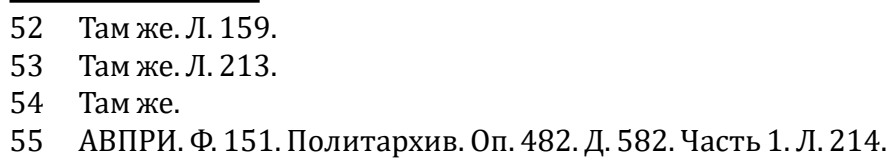


от этого только выигрывали. Единственно, что смущало венгров, по мнению дипломата, так это мнение европейской общественности, осуждавшей затягивание Будапештом заключения торгового соглашения Австро-Венгрии с Сербией. ${ }^{56}$

В начале 1909 г. В. фон Штральборн имел встречи с высокопоставленными венгерскими чиновниками, правда, их фамилии он не называл. Из этих контактов он выяснил, что в Будапеште вполне допускали возможность начала войны с Сербией и консул выяснил три направления, откуда австро-венгерские войска планировали начать наступление на Сербию (Южная Босния, Славония, Дунай). ${ }^{57}$ Скрупулезно фиксируя все передвижения австро-венгерских воинских частей по территории Венгрии и Боснии-Герцеговины, В. фон Штральборн, обратил внимание на концентрацию жандармов в Южной Венгрии. По его мнению, данное мероприятие проводилось Будапештом на случай начала войны с Сербией, после чего могли последовать массовые аресты сербов в Южной Венгрии. ${ }^{58}$

В середине марта дипломат доносил в посольство в Вене содержание выступления бывшего премьер-министра Венгрии И. Тисы в верхней палате парламента страны, где он призывал прекратить любые уступки Сербии, в том числе в экономическом плане, поскольку новые компромиссы с Белградом нанесут удар по интересам самой империи. В. фон Штральборн констатировал выражение И. Тисой настроений подавляющей части венгерской (мадьярской) общественности. ${ }^{59}$

В конце марта - апреле 1909 г. в ряде венгерских газет прошла информация о нежелательности войны с Сербией, так как она приведет к большим жертвам и к тому же в Будапеште подозревали, что за действиями Сербии стояла Россия. В европейских политических кругах стали рассуждать о том, что главным сторонником войны являлись династия и австрийская половина империи, а Венгрия выступала протии войны и более того, что в случае ее начала Транслайтания может воздержаться от активных боевых действий. В. фон Штральборн критически относился к этой информации, не

\footnotetext{
56 АВПРИ. Ф. 151. Политархив. Оп. 482. Д. 582. Часть 2. Л. 52.

57 Там же. Л. 25.

58 Там же. Л. 38.

59 Там же. Л. 32.
} 
сомневаясь в полной поддержке Будапештом войны с Сербией в случае ее начала. ${ }^{60}$

Российский дипломат в апреле 1909 г. обращает внимание МИД России еще на одно важное изменение в общественном настроении венгров (мадьяр). Если раньше они обвиняли в поддержке Сербии Россию, благосклонно относясь к Великобритании, то весной 1909 г. в венгерской печати в адрес Лондона звучала жесткая критика. Великобритания также обвинялась в поддержке Сербии. С одной стороны, это объяснялось желанием Лондона вытеснить Австро-Венгрию с сербского рынка, чтобы занять высвободившееся пространство для экспорта товаров из Великобритании. С другой стороны, британская сторона подозревалась в поддержке великосербской агитации в Южной Венгрии для ослабления Австро-Венгрии как союзницы Германии. ${ }^{61}$

В марте 1909 г. Австро-Венгрия выдвигает ультиматум Сербии с требование немедленного признания аннексии Боснии-Герцеговины. ${ }^{62}$ Белград по настоянию России и ее союзников вынужден был пойти на этот не популярный в сербском обществе шаг. Ситуация на Балканском полуострове несколько разрядилась, что поставило новые задачи перед российскими дипломатическими миссиями в Австро-Венгрии, в том числе генеральным консульством в Будапеште.

Следовательно, генеральное консульство России в Будапеште проводила активную работу по сбору средств о положении сербов в Южной Венгрии. По мнению дипломатов, сербы по сравнению с другими национальными меньшинствами Транслайтании достигли больших результатов в развитии национальной идентичности, культуры и образования. Достижения сербов во многом, по мнению российских дипломатов, базировались на их экономических успехах. Сельское хозяйство, торговля, промышленность и ремесло в сербских районах Южной Венгрии активно развивались. Диплома-

60 Там же. Л. $44-45$.

61 Там же. Л. 48-49.

62 П.А.Искендеров, „Сербия при Карагеоргиевичах“, $B$ „, пороховом погребе Европы“ . 1878-1914 г2., (Москва: „Индрик“, 2003), 382. 
ты не сомневались в том, что большую роль в развитии сербского народа в Венгрии сыграла церковная и школьная автономия сербов, полученная ими еще в конце XVII в. Дипломаты высоко оценивали деятельность различных культурно-просветительских организаций, предпринимательских структур, церкви по сохранению национальной идентичности и культуры сербского народа.

Однако в начале XX в. сербская автономия оказалось под угрозой ликвидации. Генеральное консульство выделяло несколько конфликтов, дестабилизировавших автономию сербов. Во-первых - это желание правительства Венгрии уничтожить автономию, которая мешала мадьяризации сербов и способствовала развитию сербского сепаратизма. Во-вторых, автономию сотрясали острые конфликты, развернувшиеся между духовенством и светскими политиками, стремившимися оттеснить клир от управления финансами, получаемыми от управления огромной собственностью, принадлежавшей монастырям сербской православной церкви. На взгляд дипломатов, часть средств светские деятели стремились направить на политическую борьбу. В-третьих, конфликты начались между самими сербскими политиками, в результате чего на первые роли выходят сербские радикалы. Российские дипломаты не выражали симпатий к радикалам, они их обвиняли в распространении социализма и атеизма. Это могло подорвать авторитет церкви у сербов, на протяжении многих веков сохранявшей их национальную идентичность и культуру. Дипломаты полагали, что радикалы допускали большую ошибку, их вера в социализм, атеизм, социальное равенство, в конечном итоге, уничтожала все препятствия на пути проведения политики мадьяризации сербов. В тоже время, они были далеки от идеализации духовенства, вступившего на путь сотрудничества с правительством Венгрии и не раз фигурировавшего в различных скандалах.

Генеральное консульство России в Будапеште признавало факт сотрудничества не только духовенства с правительством Венгрии. Многие сербские политические деятели пытались установить контакты с правительством и венгерскими политическими партиями, видя в них союзников в деле защиты сербов, проживавших в Хорватии и Славонии. Правда, дипломаты признавали, наметившееся в начале XX в. сближение между сербскими и хорватскими политиками, что могло благоприятно сказаться на положении сербов в Хорватии и Славонии. 
Российские дипломаты признавали влияние событий происходивших в Сербии на общественно-политическую ситуацию в сербских районах Южной Венгрии. Приезды сербских монархов в Транслайтанию, успехи Сербии во внешней и внутренней политике вызывали живой отклик со стороны сербов Венгрии и сочувствие с их стороны. Оккупация Боснии-Герцеговины Австро-Венгрией привела к обострению ее отношений с Сербией и Черногорией. В. фон Штральборн вполне допускал в конце 1908 - начале 1909 гг. возможность начала боевых действий между империей Габсбургов и Сербией.

Генеральное консульство России пристально следило за восприятием Сербии общественным мнением Венгрии. До переворота 1903 г. в Транслайтании не выражали беспокойства за политику Сербии, полагая, что она находится в дружеских отношениях с империей Габсбургов. После прихода к власти династии Карагеоргиевичей ситуация изменилась радикальным образом. Дипломаты отмечали постепенный рост в Венгрии антисербских настроений. Одним из проявлений данной тенденции становится отказ Будапешта заключить новое торговое соглашение с Сербией в кратчайшие сроки. Генеральное консульство допускало, что рост антисербских настроений могло негативно сказаться на положении сербов Южной Венгрии.

Несмотря на все проблемы, российские дипломаты, признавали, что сербы в Венгрии достигли значительных успехов в культуре, экономике, развитии национального самосознания, что позволяло им успешно противостоять политики мадьяризации и стойко защищать свои права. Даже ограничение церковной и школьной автономии не могло поколебать национальное движение сербов, занявших весомое место в экономическом и политическом пространстве Южной Венгрии в конце XIX - начале XX вв. Близость независимой Сербии только способствовала национальному возрождению сербов Южной Венгрии. 


\section{Источники и литература}

Неопубликованные источники

- Архив внешней политики Российской империи. 151. Политархив.

Периодика

- Торгово-промышленный Юг (Одесса)

Литература

- Искендеров, П. А. „Сербия при Карагеоргиевичах“. $B$ „пороховом погребе Европы“. 1878-1914 г2. Москва: „Индрик“, 2003.

- Ратнер, Н. Д. Очерки истории пангерманизма в Австрии в конце ХІХ в. Москва: Наука, 1970. 


\title{
Резиме
}

Игор Крјучков

\section{Србија и угарски Срби у извештајима Генералног конзулата Русије у Будимпешти на почетку 20. века (1901-1909)}

\begin{abstract}
Апстракт: Чланак сагледава перцепцију положаја Срба у Угарској и развоја независне Србије формирану код дипломата руског генералног конзулата у Будимпешти. Анализира се политика офанзиве мађарске владе на права Срба и узроци ове појаве. Скреће се пажња на повезаност између борбе Србије за јачање позиција на Балкану и односа Будимпеште према Србима у Угарској.

Кључне речи: Срби, Србија, Угарска, мађаризација, православна црква, аутономија, саборна црква, Нови Сад, Будимпешта
\end{abstract}

Почетком 20. века руске дипломатске мисије у Аустро-Угарској су активирале рад на прикупљању информација о националном покрету Словена и других етничких мањина Хабзбуршког царства, укључујући Србе који су живели у јужној Угарској. Овај чланак не говори о стању српског становништва у Хрватској и Славонији. Генерални конзулат Русије у Будимпешти обављао је важан посао на прикупљању информација о положају Срба у Угарској. На основу анализе архивских извора показано је да је у центру пажње руских дипломата била борба Срба за очување цркве и школске аутономије. Дипломате су уочавале да догађаји у Србији утичу на развој ситуације у српским деловима Угарске. 